\title{
Early vegetation dynamics of Pinus tropicalis Morelet forests after experimental fire (W Cuba)
}

\author{
Jorge De LAS HeRAS ${ }^{\mathrm{a} *}$, Marta BONILlA ${ }^{\mathrm{b}}$, Luis Wilfredo MARTíneZ ${ }^{\mathrm{b}}$ \\ a Escuela Técnica Superior de Ingenieros Agrónomos de Albacete, Universidad de Castilla-La Mancha, Campus Universitario s/n., \\ 02071 Albacete, Spain \\ b Facultad de Forestal, Universidad de Pinar del Río, Cuba
}

(Received 2 August 2004; accepted 10 January 2005)

\begin{abstract}
For the first time, fire effects on Pinus tropicalis Morelet (an endemic tree of Cuba) forest is studied. In January 2002, an experimental fire was carried out on a mature Pinus tropicalis forest in the Guaniguanico Mountain Range (W Cuba). Three permanent plots were set and vegetation composition and structure was studied before and one year after fire. The ecological parameters considered were: floristic richness, diversity, abundance, life forms and reproductive strategies of the vegetation. Results showed an increase in floristic richness and abundance of several species. Three endemic species appeared after fire and changes in life form rates were recorded, although pine regeneration was poor. Seeders showed a significant decrease and the number of phanerophyte species with both strategies (seedling and sprouting) increased. Results suggest that fire can be used as a tool to prevent great forest fires if avoiding soil losses and the status of surrounding vegetation is taken into consideration.
\end{abstract}

Pinus tropicalis / endemic / tropical pine forests / fire

\begin{abstract}
Résumé - Première étude sur la dynamique de la végétation des forêts de Pinus tropicalis Morelet de Cuba occidental après un feu expérimental. Pour la première fois, on étudie les effets du feu sur des forêts de Pinus tropicalis (un arbre endémique à Cuba). En janvier 2002, on a effectué un brûlage expérimental dans une forêt adulte de $P$. tropicalis dans le massif de Guaniguanico (Ouest de Cuba). Trois placettes permanentes ont été installées dans la zone à étudier et on a analysé la composition et la structure de la végétation une année après le feu. Les paramètres écologiques considérés ont été : la richesse floristique, la diversité, l'abondance, les formes de vie et la stratégie reproductive de la végétation. Les résultats indiquent une augmentation de la richesse floristique et de l'abondance d'espèces différentes. Trois espèces endémiques sont apparues après le feu et un changement significatif s'est produit dans les pourcentages des formes de vie, même si la régénération de la forêt a été très pauvre. Le nombre d'espèces se reproduisant par graines a diminué significativement tandis que le nombre d'espèces également drageonnantes a augmenté. Les résultats indiquent qu'on pourrait considérer le feu comme un outil sylvicole pour prévenir la propagation d'incendies forestiers si on considère l'état de la végétation des alentours.
\end{abstract}

Pinus tropicalis / endémique / forêts tropicales de pins / feux

\section{INTRODUCTION}

Pine forests are located on the east and west sides of Cuba. Here they are abundant in the province of Pinar del Río, occupying the northern and southern plains which surround the Sierra de los Organos and the northern half of the Isla de la Juventud. The Cuban Pine Forest ecoregion is divided into several community types [30]: pure forests of Pinus caribaea Morelet, mixed forests of Pinus caribaea and Pinus tropicalis, pure Pinus tropicalis forests, Pinus cubensis Griseb., and Pinus maestrensis Bisse [9]. In the west, this ecoregion is well represented in the Mil Cumbres Integrated Management Area (166 km², IUCN category VIII), which includes the Cajálbana plateau and the Preluda mountain region. This last area is especially well preserved and has a high number of endemic and endangered species [7]. In spite of the great number of endemic species in Cuba (3 324 species in Cuba [18]), the Cuban pine ecoregion is typically poor in endemic species due to the combination of soil characteristics and climatic conditions [11].

According to [21] and [38], about $70 \%$ of the original habitat in the Cuban pine forest ecoregion has been lost, with only three or more areas of intact habitat larger than $250 \mathrm{~km}^{2}$ remaining. The degree of fragmentation is relatively low and half of the fragments are grouped together to some extent. The rate of conversion from original to disturbed habitat is low, with a loss of about $0.5 \%$ each year [13] and more than $100 \mathrm{~km}^{2}$ of intact pine forest habitat have some degree of protection [21]. The most serious threat comes from fires that can spread rapidly through the resiniferous and xeromorphic vegetation. This could be minimized by planting latifoliate plant species that would act as a barrier and also by creating firebreaks in the forest.

\footnotetext{
* Corresponding author: jorge.heras@uclm.es
} 


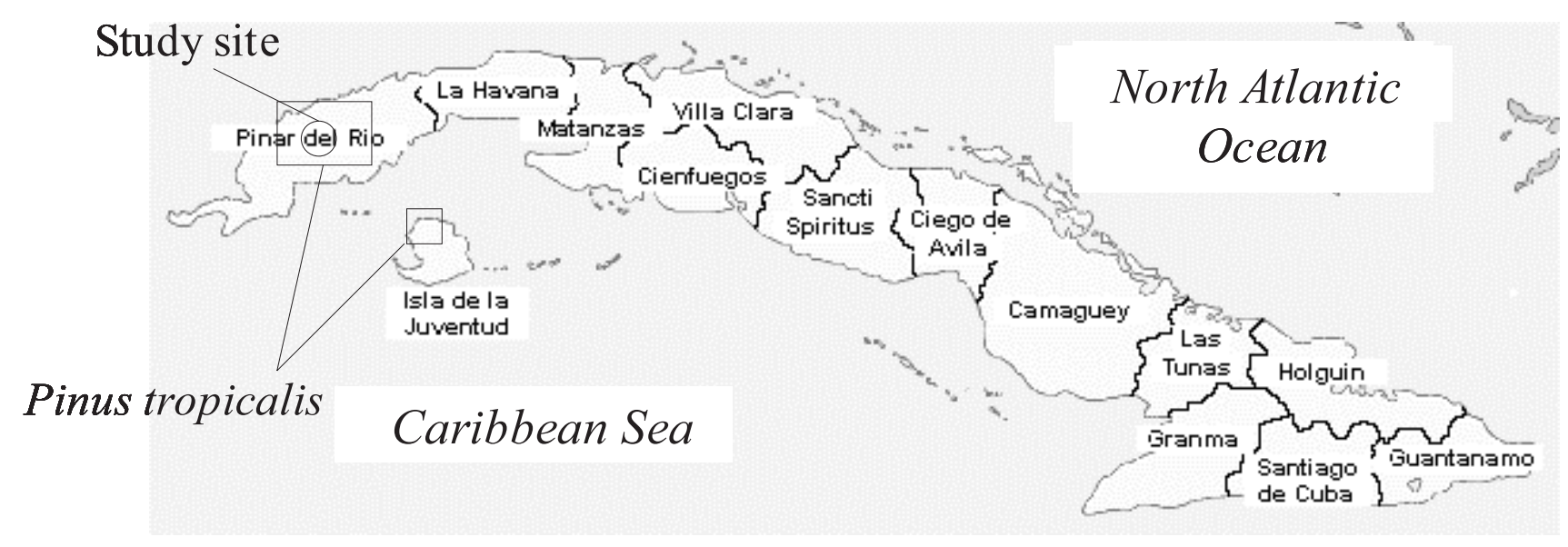

Figure 1. Distribution of Pinus tropicalis and location of the study site.

The pine forests of Pinar del Río in western Cuba represent one of the three most distinctive centers of plant diversity and endemic species in the island [28]. Despite this importance, no studies have been carried out on the vegetation dynamics of these communities after fire. However, landscape shows a mosaic of fire scars throughout the pine forests of the island. The importance of fire in tropical ecosystems outside of Cuba is also well-known $[4,16,17,23,32]$. As an example, [29] observed that fluctuations in Central and South-America tropical forests biomass burning are at least partly controlled by orbital forcing, although extra-tropical climate influences and human activity are also very important. Cochrane [15] stated that the growing prevalence of fragmentation and fire in tropical forests makes it imperative to quantify changes in these disturbances and to understand the ways in which they interact across the landscape.

The aim of this paper is to provide, for the first time, data dealing with changes in floristic composition and vegetation structure after experimental fire on a Pinus tropicalis mature forest. Dynamics of several soil parameters will be also given.

\section{STUDY SITE}

The study site is located in the Guaniguanico Mountain Range ( $22^{\circ} 41^{\prime} \mathrm{N}, 83^{\circ} 27^{\prime} \mathrm{W}$; Fig. 1). This interconnected upland region, which reaches $699 \mathrm{~m}$ in elevation and comprises two mountain chains: the western chain (Sierra de los Organos) with its northern (Alturas Pizarrosas del Norte) and southern (Alturas Pizarrosas del Sur) adjoining ranges, is primarily composed of eroded limestone block with underlying metamorphic rocks dating from the Jurassic age [31]. It is dominated by pine forests with two dominant species (Pinus tropicalis and Pinus caribaea) with dry scrub forest in the Mogotes (limestone hillocks). The resulting "haystack" karst physiography is unique in the West Indies and resembles some karst regions of southern China [31]. The zone has a typically ferralitic-quarzitic and very deep $(>100 \mathrm{~cm})$ desaturated soil $(<40 \%)$. Organic matter average is $2-4 \%$ and soils present a loam-sandy texture [10].

Annual precipitation is $1450 \mathrm{~mm}$ with a dry season from November to April and a rainy season from May to October. Average annual temperature is $25^{\circ} \mathrm{C}$, although somewhat less at higher elevations. August is the warmest month with an average temperature of $28^{\circ} \mathrm{C}$ and January is the coldest month with an average of $21.5^{\circ} \mathrm{C}[18]$.

Pinus tropicalis Morelet (pino blanco; pino hembra) is an endemic Cuban conifer, naturally distributed on sandy soils, with a preference for dry areas, in the province of Pinar del Río (Cuba's western extremity) and the municipality of Isla de la Juventud (in southeastern Cuba). In this province, there is a total surface of 67700 ha of $P$. tropicalis forest [1]. According to Price et al. [40] this two-needles per bundle species belongs to the subgenus Pinus, section Pinus, subsection Pinus. Trees grow to $20 \mathrm{~m}$ in height [8]. Trees with straight, cylindrical boles may reach heights of $30 \mathrm{~m}$ and an aboveground diameter of $30 \mathrm{~cm}$ at breast height, with rough bark and deep fissures. The trees flower from January to May, with the peak period in late March-early April. Development continues throughout the remainder of the year, with maturity in July-August of the following year, at which time dehiscence and seed release took place. Mature trees aged 10 to 20 years exhibit some needle fall and the needles sprouting between March and June. Its characteristic pattern of herbaceous growth in the first three years after planting followed by an accelerated process of vertical growth sometimes associated with the appearance of "fox tail" phenotypes, have induced a tendency among forest companies in western Cuba to replace this species by $P$. caribaea var. caribaea after felling in its natural areas. This has justifiably aroused national and international concern over the risk of genetic erosion of this fast-growing tropical conifer [40].

Vegetation of the study site is made up of a 20 years old Pinus tropicalis tree canopy with $12 \mathrm{~m}$ average height of and $18 \mathrm{~cm}$ average diameter. The pine stand in the study zone was $>70$ years old. Vegetation associated to the pine canopy was primarily composed of shrub species, grasses and liana species. However, floristic richness was significantly low in comparison to that recorded for other pine tropical forests of Central America and Caribe [27].

\section{MATERIALS AND METHODS}

Three $50 \times 100 \mathrm{~m}^{2}$ permanent plots were set in the study zone. Location of each plot was selected considering similar vegetation and soil homogeneity, low slope (average slope was 13\%), same exposure 
Table I. Experimental burning conditions. Data are average values of each plot.

\begin{tabular}{ccccc}
\hline $\begin{array}{c}\text { Plots } \\
\text { B }(\mathrm{cm})\end{array}$ & $\begin{array}{c}\text { Litter layer depth } \\
(\mathrm{cm})\end{array}$ & $\begin{array}{c}\text { Litter layer depth A } \\
(\mathrm{cm})\end{array}$ & $\begin{array}{c}\text { Flame length } \\
\left(\mathrm{ms}^{-1}\right)\end{array}$ \\
\hline 1 & 11 & 3.01 & 0.78 & 0.0102 \\
2 & 11.63 & 3.2 & 2.12 & 0.0524 \\
3 & 7.95 & 3.7 & 0.74 & 0.0061 \\
\hline
\end{tabular}

(N) and altitude (200 m a.s.1.). Average cover of vegetation was: $70 \%$ tree layer, $80 \%$ scrub layer and $90 \%$ herbaceous layer. Density of pine stands was 223 trees ha ${ }^{-1}$. A $25-\mathrm{m}$ separation was left between plots in order to prevent border effects. Plots were submitted to three experimental fires in January 2002 after a five-day period with no precipitation. During fire, flame length and speed was measured using metal pins distributed each meter along two borders of every plot, (burning conditions can be seen in Tab. I).

Burning was carried out using a backing fire line of $50 \mathrm{~m}$, while total burnt surface was 2 ha.

Before burning, six soil samples were randomly taken from two layers in each plot: 3 samples from $0-10 \mathrm{~cm}$ depth and 3 more form $10-20 \mathrm{~cm}$ depth below the previous. Several soil parameters were analysed: $\mathrm{pH}$ (in saturated soil water paste); $\mathrm{P}$ available [44]; soil organic matter $(\mathrm{OM})$ using the wet digestion with acid-dichromate and heat; $\mathrm{Ca}^{2+}, \mathrm{Mg}^{2+}, \mathrm{Na}^{+}$and $\mathrm{K}^{+}$(atomic absortion spectrometry). This soil sampling was also carried out one year after fire and the same soil parameters were analysed. Climate conditions (relative moisture and temperature) during burning can be seen in Figure 2.

After experimental burning, vegetation was completely killed. Prior burning (December 2001) and after burning (February 2003) vegetation was studied. For this study, five $25 \mathrm{~m}$ lines were set in each plot and vegetation sampling was carried out using the line intercept method [12]. To take the field data, $25 \mathrm{~m}$ length ropes, wooden pins, $1 \mathrm{~m}$ length needles (for vertical measures) and a field metre, were used. With field sampling, several ecological parameters were obtained, i.e., floristic richness, species abundance and diversity index (using the Shannon-Weaver index). Furthermore, [41] life forms and reproductive strategies considering seeders, sprouters and both were also studied. Fire effect on dynamics of endemic flora was also considered.

Data was subjected to Anova treatments in order to determine significant differences between data groups and the method used to discriminate among the means was the Fisher least significant difference (LSD) for $p<0.05$. To ensure that data were normally distributed, standarized skewness and standarized kurtosis values were checked. Percentage values corresponding to the cover value for each species were arcsin transformed. A PCA analysis was carried out considering average species abundance as variables. The purpose of the analysis was to obtain a small number of linear combinations of 16 variables

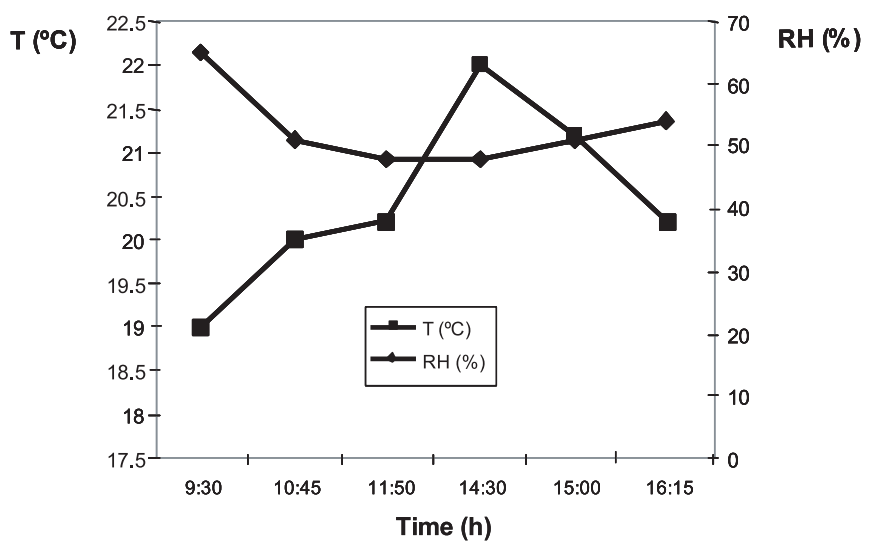

Figure 2. Temperature $\left({ }^{\circ} \mathrm{C}\right)$ and relative humidity $(\%)$ during burning.

(species with abundance value $<5 \%$ were removed from the analysis) which account for most of the variability in the data. In this case, the first 2 components account for $58.17 \%$ of the variability in the original data.

Taxa nomenclature is based on Gledhill [26], Greuter [28].

\section{RESULTS}

\subsection{Soil}

Consumption of litter layer during fire was up of $50 \%$ in the three plots (Tab. I). Significant differences were obtained between upper layers of soil (0-10 cm depth) at different sites when they were compared before and after fire (Tab. II). Thus, a significant increase in $\mathrm{P}$ available, $\mathrm{Mg}^{2+}$ and $\mathrm{Na}^{+}$were detected in this layer. However, no significant variations occurred for $\mathrm{pH}$ and organic matter content. In the case of the deeper layer (10-20 cm depth), an increase in the organic matter content and a decrease in the $P$ available were recorded. Cations studied did not vary significantly in this layer with the exception of $\mathrm{Mg}^{2+}$ content. $\mathrm{Na}^{+}$showed differences in content in lower layer. As a monovalent cation, it would sink deeper into soil relative to divalent cations.

\subsection{Floristic richness and diversity}

Before fire, average floristic richness was significantly homogeneous in the three study plots $(6 \pm 1.96)$. A total of

Table II. Soil parameters analysed for samples taken from two layers $(0-10 \mathrm{~cm}$ depth and $10-20 \mathrm{~cm}$ depth $)$ in the study zone. BF: Before fire. AF: One year after fire. Different letters mean significant differences between layers compared before and after fire $($ at $p<0.05)$ among the three plots.

\begin{tabular}{|c|c|c|c|c|}
\hline & $\mathrm{BF}(0-10 \mathrm{~cm})$ & $\mathrm{BF}(10-20 \mathrm{~cm})$ & $\mathrm{AF}(0-10 \mathrm{~cm})$ & $\mathrm{AF}(10-20 \mathrm{~cm})$ \\
\hline $\mathrm{pH}$ & $3.64 \pm 0.11 \mathrm{a}$ & $3.74 \pm 0.12 \mathrm{a}$ & $3.65 \pm 0.09 a$ & $3.72 \pm 0.12 \mathrm{a}$ \\
\hline $\mathrm{OM}(\%)$ & $3.27 \pm 0.12 \mathrm{a}$ & $2.4 \pm 0.09 a$ & $2.87 \pm 0.01 b$ & $3.36 \pm 0.07 b$ \\
\hline $\mathrm{P}$ available $(\mathrm{mg} / \mathrm{kg})$ & $0.83 \pm 0.01 \mathrm{a}$ & $0.51 \pm 0.02 \mathrm{a}$ & $1.5 \pm 0.01 b$ & $1.05 \pm 0.01 b$ \\
\hline $\mathrm{Ca}^{++}(\mathrm{mg} / \mathrm{kg})$ & $0.66 \pm 0.01 \mathrm{a}$ & $0.69 \pm 0.01 \mathrm{a}$ & $0.54 \pm 0.01 b$ & $0.90 \pm 0.02 b$ \\
\hline $\mathrm{Mg}^{++}(\mathrm{mg} / \mathrm{kg})$ & $0.21 \pm 0.01 \mathrm{a}$ & $0.19 \pm 0.01 \mathrm{a}$ & $0.31 \pm 0.01 b$ & $0.34 \pm 0.01 b$ \\
\hline $\mathrm{Na}^{+}(\mathrm{mg} / \mathrm{kg})$ & $0.026 \pm 0.001 a$ & $0.032 \pm 0.001 \mathrm{a}$ & $0.08 \pm 0.01 b$ & $0.117 \pm 0.007 b$ \\
\hline $\mathrm{K}^{+}(\mathrm{mg} / \mathrm{kg})$ & $0.13 \pm 0.01 \mathrm{a}$ & $0.09 \pm 0.01 \mathrm{a}$ & $0.157 \pm 0.01 \mathrm{a}$ & $0.113 \pm 0.01 b$ \\
\hline
\end{tabular}




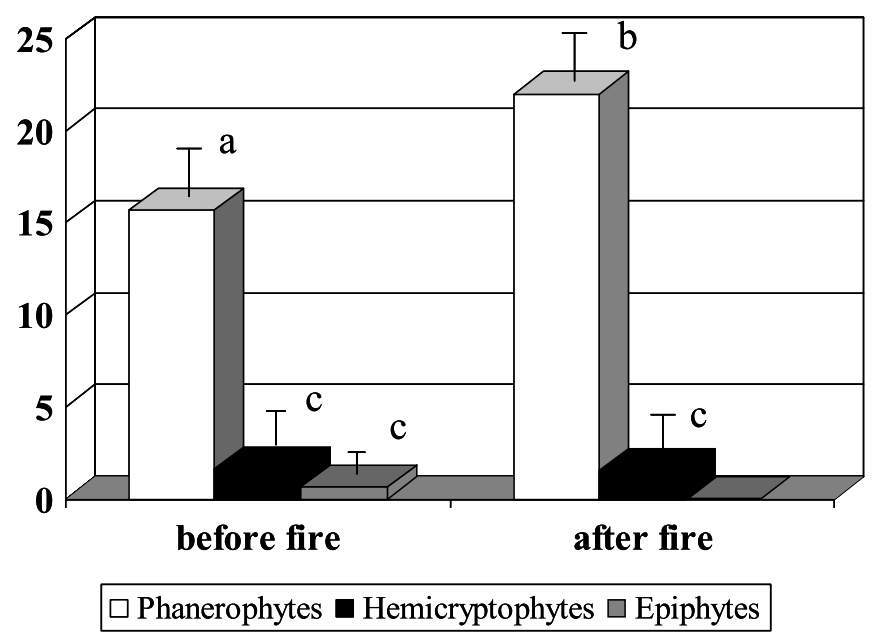

Figure 3. Average species life forms before and after fire in the study plots. Different letters mean significant differences at $p<0.05$.

18 species was recorded, the most frequent being Pinus tropicalis, which was present in all recorded samples. The shrub canopy was represented by Curatella americana L. $(66.67 \%$ of total samples), Amaioua coryimbosa H.B.K. (33.33\%), and Clusia rosea L. (33.13\%) and the tree fern Cyatea arborea (33.3\%) among others. The most abundant species in the herbaceous layer were Byrsonima spicata (Cav.) DC. (66.6\% but present also in the shrub canopy), Clidemia hirta (L.) D. (50\%) Xylopia aromatica (Lam.) Mart. (50\%), Eragrostis pilosa (L.) P. Beauv. (33.33\%) and Matayba apetala (Macfad.) Radlk. ( $50 \%$ but also recorded as a shrub). It is important to note the high presence of liana species such as Cuscuta americana L. (50\%) and Davilla rugosa Poiret (16.67\%).

After fire, the tree canopy was killed although the flame length did not reach the tallest tree crowns such as those of Pinus tropicalis and only seedlings coming from the seed bank or surrounding areas could be recorded in the herbaceous canopy. This is the case of Pinus tropicalis (11.1\%), Cyrilla racemifolia L. (11.37\%) and Rondeletia correifolia (Griseb.) Borhidi \& Fernández (11.1\%). The number of recorded species was higher than that before fire (22) and homogeneous in the three plots $(9 \pm 1.9)$. It is important to note the high presence of several species that were not recorded before fire, i.e., Sorghastrum stipoides (Kunth) Nash (55.6\% of total samples), Odontosoria writghiana Maxon. (33.3\%) and Erigeron spp. $(33.32 \%)$.

As for endemic species, Tetrazigia coreacea Urb. increased its presence after fire (from $16.67 \%$ to $100 \%$ ) and two endemic plants absent in unburnt plots (Rondeletia correifolia and Mitracarpus glabrescens (Griseb.) Urb.) appeared after fire with different percentages ( $44.4 \%$ and $11.1 \%$ respectively). Pinus tropicalis, present in $100 \%$ samples, was also recorded after fire $(11.1 \%)$.

The Shannon-Weaver diversity index was not significantly different before and after fire $(1.19 \pm 0.12$ and $1.12 \pm 0.15$ respectively).

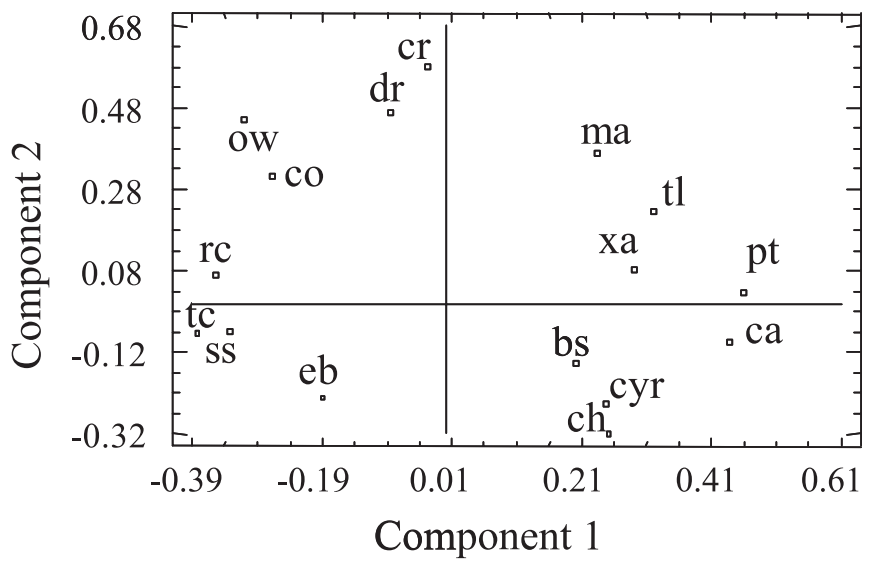

Figure 4. Principal Component Analysis considering average species abundance as a variable. Species with an abundance value $<5 \%$ were previously removed from analysis. The two first components account for $58.17 \%$ of the variability in the original data. pt: Pinus tropicalis; ca: Curatella americana; tl: Tabebuia lepidophylla; cyr: Cyrilla racemifolia; ch: Clidemia hirta; bs: Byrsonima spicata; xa: Xylopia aromatica; ma: Mataiba apetala; rc: Rondeletia correifolia; cr: Clusia rosea; dr: Davilla rugosa; eb: Erigeron bellatroides; ow: Odontosoria wrigthiana; tc: Tetrazigia coreacea; ss: Sorghastrum stipoides; co: Coccocypselum hirsutum.

\subsection{Abundance}

PCA analysis (Fig. 3) showed a significant tendency marked by Component 1 . Higher positive values correspond to those species with abundance decrease after fire (Curatella americana, Pinus tropicalis, Tabebuia lepidophylla, Cyrilla racemifolia L. and Xylopia aromatica among others). However, high negative values of the component 1 correspond to those species with a significant abundance increase after fire (Tetrazigia coreacea, Rondeletia correifolia, Coccocypselum hirsutum Bartl. ex DC. Sorghastrum stipoides and Odontosoria wrigthiana). The two first components account for $58.17 \%$ of the variability in the original data.

\subsection{Life forms and reproductive strategies}

Vegetation changes dealing with life forms were intense. In plots before fire, $87 \%$ of the total species corresponded to phanerophytes, $9 \%$ to hemicryptophytes and $4 \%$ to epiphytes. However, after-fire epiphytes were absent and phanerophytes increased (93\%). The hemicryptophyte average rate was $7 \%$. No significant differences were found between average hemicryptophyte species before and one year after fire (Fig. 4).

In relation to dynamics of reproductive strategies, only seeders decreased significantly (Fig. 5). Presence of seeders and species with both strategies (seeders and sprouters) did not vary significantly.

\section{DISCUSSION}

The effects of fire on vegetation and soil dynamics depend on several factors. Among these, fire intensity and frequency have shown to be significant variables that act on seed survival, 


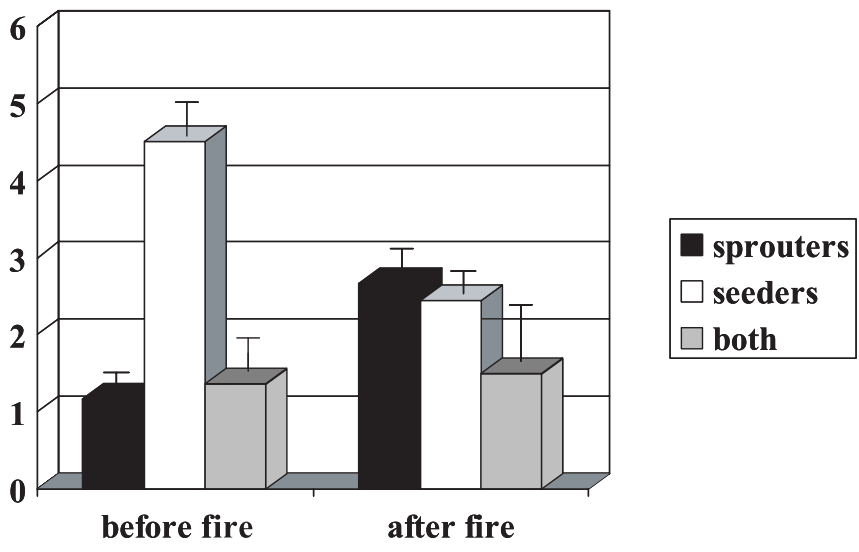

Figure 5. Average of the number of species recorded before and after fire in considering their reproductive strategies (seeders, sprouters and both strategies). Different letters mean significant differences at $p<$ 0.05 .

density, mortality, height, crown area, plus basal diameters of seedlings and sprouts in tropical forests [33]. On the other hand, site quality and vegetation structure and composition before fire have to be considered as very important factors to determine the early stages of secondary succession [20, 22, 45].

Studies dealing with tropical soil dynamics after fire note a significant increase in nutrient levels, $\mathrm{pH}$ and also a decrease in heavy metals such as aluminium when soil samples are taken a few days after fire [32]. However, after one year, losses by lixiviation result in lower nutrient reserves in the soil than before the fire. In this study, nutrient reserves in the upper layer (0-10 cm depth) one year after fire, were similar to levels obtained before fire. These results are more in accord with those obtained in pine forests of temperate and Mediterranean zones than in tropical forests [19]. Furthermore, [24] noted that fire affected microbial activity by means of both soil heating and chemical changes in tropical deciduous forests, although these effects were only shown a few years after fire.

The total consumption of vegetation in the experimental fire carried out in this study did not eliminate the majority of species composing the plant communities in the early stage of succession. Total mortality of species in the tree canopy could be explained by the absence of survival strategies. In this sense [4, 5] noted that trees surviving the fire had significantly thicker bark than living trees in unburnt forest plots, indicating that thin-barked trees are more prone to selective mortality induced by heat stress. In the study zone, floristic richness increased and $50 \%$ of species recorded before fire were also found one year after fire. In this sense, several species such as Cassyta filiformis L., Andropogon gracilis Spreng., Amaioua corymbosa Kunth., Pulchea rosea Godfrey and Coccocypselum hirsutum among others appeared after fire for the first time in the study. In this sense, floristic composition one year after fire is related to that of Pinus elliotii var. densa Little \& KW Dorman and Pinus palustris Miller ecosystems in central Florida, with a known fire regime, although fire response of Cuban pine forests present significant differences as can be seen in the present study [37]. Furthermore, 3 endemic species appeared after fire:
Mitracarpus glabrescens, Tetrazigia coreacea, Rondeletia correifolia whereas only $T$. coreacea was found before fire. This can be explained for several ecosystems well adapted to fire [20]. Relative frequencies of plant species occurrence are changed by fire, and plant species representing earlier successional stages are introduced into burnt ecosystems [34, 42]. Communities of postfire plant species, therefore, are often similar to prefire communities or communities existing on adjacent unburnt areas [20]. Fire-stimulated germination of seeds that have been stored in the soil can contribute to the regeneration of many species. In the case of the main tree species (Pinus tropicalis) a significant decrease in its frequency was noted after fire. It seems that the most part of mature seeds in the cones and those in the soil bank died during fire, so regeneration came primarily from trees located in surrounding unburnt areas. In mature forests with pine species that have serotinous cones, large scale pine regeneration is frequent one year after fire [27]. Marod et al. [36] suggested that different species have adaptations related to the season of seedling emergence and resistance to drought in tropical seasonal forest communities. Most species in seasonal tropical forests have adapted to fire and/or drought by resprouting, seed bank or a combination of both.

In relation to abundance and diversity variations, diversity values were low and very different to those obtained in mature pine forests from other ecosystems from temperate and Mediterranean climate zones [3] but also to those of tropical forests $[6,25]$. Results obtained in this study agree with those found by i.e., in [14] tropical pine forests, diversity index may decrease due to climate change, but it increases significantly with a combination of climate change, logging and/or fire. Removing all individuals of each single species significantly affects the diversity of the ecosystem. After the removal of shade tolerant species, the diversity index experiences a significant change. In any case, diversity values depend on work scale and results have to be considered merely as a reference [39].

The more significant changes were obtained in the case of life forms and reproductive strategy rates. Intolerant plants released from a relatively shaded position to one that is suddenly fully-exposed may show a decrease in growth (cover) or may actually die. In sites where prescribed fires are used on clear-cuts, diversity value increases during the early stages after silviculture operations, and after a few years, it decreases to the values before perturbation [35].

Dominancy of therophytes during the early stages of succession after fire and their scarcity in mature stages have been observed in Mediterranean forests. González-Ochoa et al. [27] noted that this pattern is favoured by an increase in light, an absence of humus and a nutrient increase in the upper soil layers. Furthermore, therophyte dynamics are related to germination mechanisms [2]. The majority of species that appear immediately after fire have seeds whose germination capability is induced by high temperatures during fire. Verroios and Georgiadis [43] noted that therophytes present in young Pinus halepensis stands can reach $50 \%$ of all species recorded during the first two years after fire. In the study zone, therophyte role is played by phanerophytes with both reproductive strategies: seedling and sprouting. Significant seeders decrease one year after fire, thus determining the high dependence of plant regeneration from surrounding unburnt areas. Regeneration capability of many species of obligate seeders suffered the effects of fire. 
As a conclusion, considering both soil and vegetation results, experimental fire affected vegetation structure and floristic composition of Pinus tropicalis forests, while the effect of fire on the soil parameters considered was also significant. One year after fire diversity they did not vary significantly, and the presence of endemics even increased. Regeneration of Pinus tropicalis forests after fire depends on surrounding unburnt areas. In this sense, prescribed fire could be used to prevent great fires if surrounding vegetation status (pine canopy age, diversity and structure), is taken into consideration. However, further studies must be realized dealing with dynamics of $P$. tropicalis forests vegetation and soils after fire to consider firmly fire as a silviculture tool in those ecosystems of Cuba.

\section{REFERENCES}

[1] Alvarez A., Suárez J.T., Hechavarría O., Diago I., Pinus tropicalis Morelet: its characteristics and genetic resource status, FAO Document Repository n ${ }^{\circ} 29$, Forest Genetic Resources, 2001.

[2] Awada T., Henebry G.M., Redmann R.E., Sulistiyowati H., Picea glauca dynamics and spatial pattern of seedlings regeneration along a chronosequence in the mixedwood section of the Boreal Forest, Ann. For. Sci. 61 (2004) 661-666.

[3] Agee J.K., Fire and pine ecosystems, in: Richardson D.M. (Ed.), Ecology and biogeography of Pinus, Cambridge University Press, Cambridge, 1998, pp. 193-218.

[4] Barlow J., Lagan B.O., Peres C.A., Morphological correlates of fire-induced tree mortality in a central Amazonian forest, J. Trop. Ecol. 19 (2003) 291-299.

[5] Barlow J., Peres C.A., Lagan B.O., Haugaasen T., Large tree mortality and the decline of forest biomass following Amazonian wildfires, Ecol. Lett. 6 (2003) 6-8.

[6] Batista J.L.F., Maguire D.A., Modelling the spatial structure of tropical forests, For. Ecol. Manage. 110 (1998) 293-314.

[7] Berazaín R., Notas sobre la vegetación y flora de la Sierra de Cajálbana y Sierra Preluda (Pinar del Río), Revista del Jardín Botánico Nacional 8 (1987) 39-68.

[8] Bisse J., Árboles de Cuba, Editorial Científico-Técnica, Ciudad de la Habana, Cuba, 1988.

[9] Bordhini A., Phytogeography and Vegetation Ecology of Cuba, Akadémiai Kiadó, Budapest, 1991.

[10] Cairo P., Fundora O., Edafología, Editorial Pueblo y Educación, La Habana, 1994.

[11] Campbell D.G., Hammond H.D., Floristic inventory of tropical countries: the status of plant systematics, collections, and vegetation, plus recommendations for the future, New York Botanical Garden, New York, 1989.

[12] Canfield R.H., Application of the line intercept methods in sampling range vegetation, J. For. 39 (1941) 388-394.

[13] Caribbean Environmental Programme (C.E.P.), Status of Protected Area Systems in the Wider Caribbean Region, C.E.P. Technical Report N 36, 1996.

[14] Chen X.W., Li B.L., Tree diversity change in remaining primary mixed-broadleaved Korean pine forest under climate change and human activities, Biodivers. Conserv. 13 ( 2004) 563-577.

[15] Cochrane M.A., Synergistic interactions between habitat fragmentation and fire in evergreen tropical forests, Conserv. Biol. 15 (2001) 1515-1521.

[16] Cochrane M.A., Fire science for rainforests, Nature 421 (2003) 913-919.
[17] Cochrane M.A., Alencar A., Schulze M.D., Souza C.M., Nepstad D.C., Lefebvre P., Davidson E.A., Positive feedbacks in the fire dynamic of closed canopy tropical forests, Science 284 (1999) $1832-1835$.

[18] Davis S.D., Heywood V.H., Herrera-Macbryde O., Villa-Lobos J., Hamilton A.C., Centres of plant diversity. A guide and strategy for their conservation, Vol. 3, The America's World Wildlife Fund, Washington D.C., 1997.

[19] De las Heras J., Guerra J., Herranz J.M., The role of bryophytes in the nitrogen dynamics of soils affected by fire in Mediterranean forests (SE Spain), Ecoscience 3 (1996) 199-204.

[20] DeBano L., Neary D., Folliott D.G., Fire's effects on ecosystems, John Wiley and Sons, Inc., New York, 1998.

[21] Dinerstein E., Olson D.M., A Conservation Assessment of the Terrestrial Ecoregions of Latin America and the Caribbean, The World Bank in association with WWF, Washington D.C., 1995.

[22] Fernández P.A.M., Loureiro C.A., Botelho H.S., Fire behaviour and severity in a maritime pine stand Ander differing fuel conditions, Ann. For. Sci. 61 (2004) 537-544.

[23] Gerwing J.J., Degradation of forests through logging and fire in the eastern Brazilian Amazon, For. Ecol. Manage. 157 (2002) 131-141.

[24] García-Oliva F., Sanford R.L., Kelly E., Effect of burning of tropical deciduous forest soil in Mexico on the microbial degradation of organic matter, Plant Soil 206 (1998) 29-36.

[25] Galindo-Jaimes L., González-Espinosa M., Quintana-Ascencio P., García-Barrios L., Tree composition and structure in disturbed lands with varying dominance by Pinus spp. In the highlands of Chiapas, Mexico, Plant Ecol. 162 (2002) 259-272.

[26] Gledhill D. The names of plants, 3rd ed., Cambridge University Press, New York, 2002.

[27] González-Ochoa A.I., López-Serrano F.R., De Las Heras J., Does post-fire forest management increase tree growth and cone production in Pinus halepensis? For. Ecol. Manage. 188 (2004) 235-247.

[28] Greuter W., International Code of botanical nomenclature: (Tokyo Code) adopted by the 15th International Botanical Congress, Konigstein, Koeltz Scientific Books, 1994.

[29] Haberlee S.G., Ledru M.P., Correlations among charcoal records of fires from the past 16000 years in Indonesia, Papua New Guinea and Central and South America, Q. Res. 55 (2001) 97-104.

[30] Hernández J.R., Atlas de Cuba: mapa de la vegetación original de Cuba. Map 1:2 000 000, Instituto de Geografía de Cuba, Havana, Cuba, 1989.

[31] Hedges S.B., Distribution patterns of amphibians in the West Indies, in: Duellman W.E. (Ed.), Patterns of distribution of amphibians: A global perspective, The John Hopkins University Press, Baltimore, 1999, pp. 211-254.

[32] Ivanauskas N.M., Monteiro R., Rodrigues R.R., Alterations following a fire in a forest community of Alto Rio Xingu, For. Ecol. Manage. 184 (2003) 239-250.

[33] Kennard D.K., Gould K., Putz F.E., Fredericksen T.S., Morales F., Effect of disturbance intensity on regeneration mechanisms in a tropical dry forest, For. Ecol. Manage. 162 (2002) 197-208.

[34] Krefting L.W., Ahlgren C.E., Small mammals and vegetation changes after fire in a mixed conifer-hardwood forest, Ecology 55 (1974) 1391-1398.

[35] Lewis C.E., Swindel B.E., Tanner G.W., Species diversity and diversity profiles, concept, measurement and application to timber and range management, J. Range Manage. 41 (1988) 466-469.

[36] Marod D., Kutintara U., Tanaka H., Nakashizuka T., The effects of drought and fire on seed and seedling dynamics in a tropical seasonal forest in Thailand, Plant Ecol. 161 (2002) 41-57. 
[37] Myers R.L., Ewel J.J., Ecosystems of Florida, University of Florida Press, 1990.

[38] Olson D., Dinerstein E., Castro G., Maravi E., Identifying gaps in botanical information for biodiversity conservation in Latin America and the Caribbean, World Wildlife Fund, Washington D.C., 1996.

[39] Pausas J.G., Carbo E., Neus R., Gil J.M., Vallejo R., Post-fire regeneration patterns in the eastern Iberian Peninsula, Acta Oecol. 20 (1999) 499-508.

[40] Price R.A., Liston A., Strauss S.H., Phylogeny and systematics of Pinus, in: Richardson D.M. (Ed.), Ecology and Biogeography of Pinus, Cambridge University Press, New York, 1998, pp. 49-68.

[41] Raunkaier C., The life forms of plants, Clarendon Press, Oxford, 1934.
[42] Stransky J.J., Harlow R.F., Effects of fire on deer habitat in the Southeast prescribed burning, in: Wood G.W. (Ed.), Prescribed fire and wildlife in southern forests, Belle W. Baruch Forest Science Institute, Clemson University, Georgetown, South Carolina, 1981, pp. 135-142.

[43] Verroios G., Georgiadis T., Post-fire vegetation succession: the case of Aleppo pine (Pinus halepensis Miller) forests of northern Achaia (Greece), Fresenius Environ. Bull. 11 (2002) 186-193.

[44] Watanabe F.S., Olsen S.R., Test of an ascorbic acid method for determining phosphorus in water and $\mathrm{NaHCO}_{3}$ extracts from soils, Soil Sci. Soc. Am. Proc. 20 (1966) 677-678.

[45] Zwolinski M.J., Fire effects on vegetation and succession, in: Krammes J.S. (Ed.), Effects of fire management of southwestern natural resources, USDA For. Serv., Gen. Tech. Rep. RM-191, 1990, pp. 18-24. 